\title{
ZALAVÁRI JÓZSEF ÉS AZ ELSŐ PILLANAT HATÁSA \\ JÓZSEF ZALAVÁRI AND THE POWER OF THE FIRST INSTANT
}

\author{
Frans Jeursen \\ művészettörténész \\ f.jeursen@planet.nl
}

\section{ÖSSZEFOGLALÁS}

Zalavari József múvei egyértelműen kapcsolódnak a matematikához, de ezúttal nem az ember által létrehozott dologként, hanem sajátos formai és tartalmi valóságként, lehetősége szerint mint valóságegészként. A matematika egyszerre alapvető, és megérinti az abszolútumot, amely a saját üzenetét küldi, ahogyan azt a Zalavari-féle műalkotásokban is teszi. Az abszolútum minden idő „első pillanatában” szólal meg, úgy emelkedik fel, mint egy oszlop, amely a világegyetemet tartja. Az első teremtő pillanat okozza az idő és a mozgás különbségét is, amely a világát teremtő emberi szubjektum körül kering. Ugyanakkor a tiszta emberi végességet idézi fel. Zalavari karcsú, függőleges szobrai ezt a végesség-végtelenség összjátékot mutatják be bemélyedésekkel és váltakozó fényhatásokkal. Így visszavezetik az emberi elmét az abszolútumban létező alapjához. Ez mindkét végletet hangsúlyozza; az abszolút formát/tartalmat és a kreatív emberi időt, jobban mondva az időt mint emberi kreativitást.

\begin{abstract}
József Zalavári's artworks have a clear link to mathematics, this time not seen as something man produced but as a reality of form and content in its own right, possibly all of reality. Mathematics is basic and also touching the absolute that sends out its own message, as it also does in works of art like Zalavári's. The absolute speaks in the 'first instant' of all time, rising up like a pillar holding up the universe. The first creative instant also causes the difference of time and movement circling the human subject creating his world. At the same time it evokes pure human finiteness. Zalavári's slender vertical sculptures show this finity-infinity interplay by indentations and alternating spots of light. Thus they bring the human mind back to its base in the absolute. This stresses both ends; absolute form/content and creative human time, better; time as human creativity.
\end{abstract}

Kulcsszavak: konkrét művészet, redukált formarend, dekonstrukció, első pillanat

Keywords: concrete art, reduced form, deconstruction, first instant 
Zalavári József szobrai, fali domborművei és papírmunkái elsőre egyszerűnek tűnnek, néha talán kicsit túl egyszerünek. Nem vonzónak azon mükedvelők számára, akik színekre, mozdulatokra és felismerhető jelenetekre, talán egy őszi erdőre, a nyugtalan tengerre vagy olyan emberekre vágynak, akiket ismernek vagy szépségük miatt csodálnak. Ezek közül egyik sem található meg Zalavári mủvei között: három vagy négy papírdarab, egy hosszú fémszalag, néha kettő, bennük esetleg holtpontok, néha részben csavartak, a felület itt-ott matt és csiszolt. Egy négyfelé hajtott felület, az egyik rész tökéletlen, néha hasított és így tovább. Általában csendet idéznek. Azonban hamarosan felmerül egy csodálatos érzés, a béke legkisebb zavara és egy hajszálvonal törése a lineáris időben, mely párhuzamosan halad a puszta csenddel.

„Zalavári mélyen intellektuális müvész. Minimális, vagyis hogy néha már-már minimalista eszköztárral dolgozik, és eközben hihetetlenül sokat mond a térről, a fényről és a mozgásról. Túl egyszerű lenne azt mondani, hogy munkássága egyenes folytatása a zürichi konkrétoknak, bár számomra ez már magában is a minőség vélelmezhetőségét jelentené, de az kétségtelen, hogy a Max Bill-i örökség nála egyértelmủ. Talán nem annyira formavilágában, hiszen más utat jár, mint Bill a »harmonikus mérték és törvény« megtalálásában, de plasztikai megfogalmazásának szigorúságában és igényességében, valamint feladatának axiomatikus megfogalmazásában mindenképpen a konkrét müvészet esztétikai programját tekinti számára mértékadónak. Gyanítom, hogy formatani vizsgálódásai - és egy, a növendékei számára tisztességgel vállalható vizuális oktatási program kidolgozása - során jutott el morfémáihoz.

A morfémák egy háromdimenziós vizuális nyelv mondatai, ahol a nyelv szavai (elemei) egy eggyel alacsonyabb dimenzióban vannak definiálva. Ezek az elemek a következők: a kör, a háromszög és a négyszög. A morfémák nyelvtana, ami tehát a szavakat kapcsolja össze adott szabályok szerint, szintén minimális. Zalavári nyelvtana két műveletet alkalmaz: a bemetszést és a hajtást - mindkettőt többszörösen megengedve. Mindössze ezzel a két művelettel és a három síkformával hoz létre hihetetlenül izgalmas, elegáns és meghökkentően új háromdimenziós tereket. Szigorú, de mégis játékos szerkezetek ezek. Zalavári munkamódszerét illetően is Bill diktátumára hallgat: »...a müvész munkája jelentős mértékben a tartalom matematikai megközelítésében lelhető fel...«." (Szöllősi-Nagy, 2005)

A matematikával való szoros kapcsolat nyilvánvaló; a számok, vonalak, négyzetek és felületek abszolút tökéletessége. Az első szint egy sík határtalan felülete, mely kezdet vagy vég nélkül terjed minden irányban, a mozgás nélküli örökkévalóság képe. Sok filozófus, mint például Plótinosz, is tünődött ezen; ,,azonosság” és „egység”, ezek tartalmai és jelentése, Istenhez való közelség vagy akár azonosság, jellegzetes jegyek, tulajdonságok vagy mennyiségek nélkül. A költők, akiket mindezek lenyügöztek „Isten arcának érintéséről” beszéltek, és megpróbálták megnevezni vagy akár keretbe foglalni a meg nem nevezhetőt és a keretbe nem foglalhatót. 


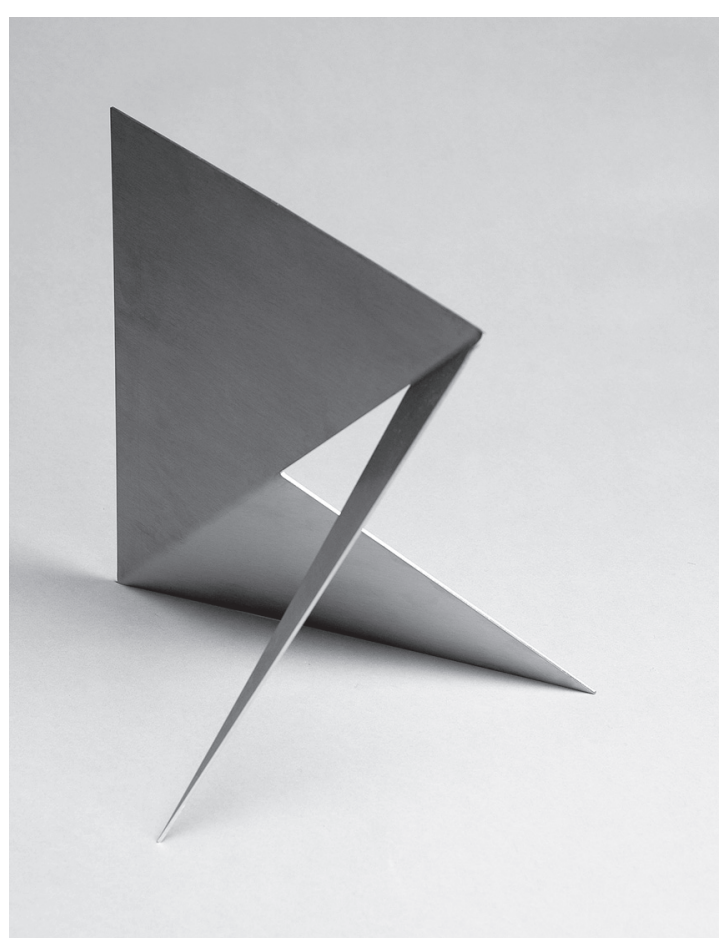

1. ábra. Térhárom / Spacetree, 2004, rozsdamentes acél, $27 \times 30 \times 17,5 \mathrm{~cm}$

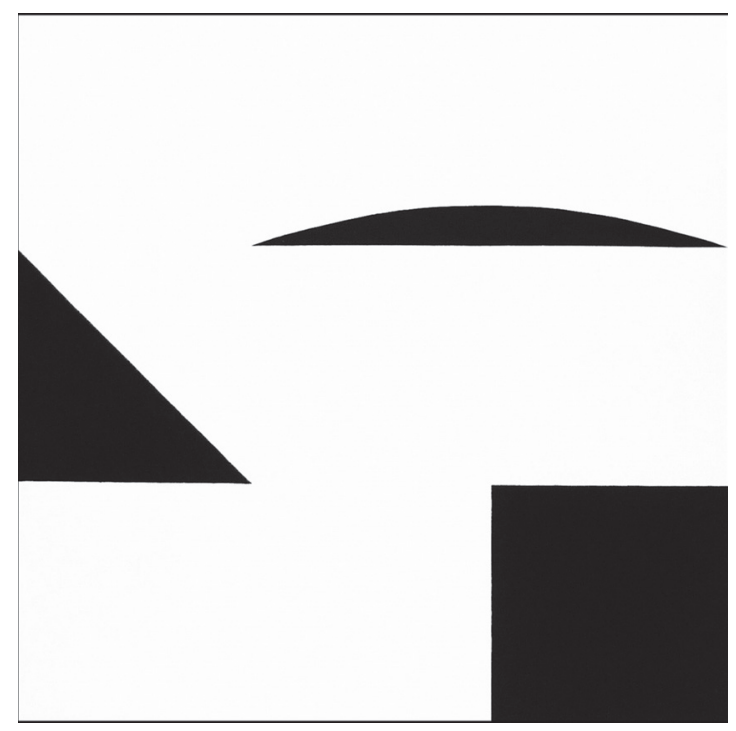

2. ábra. Kilenc forma / Nine form, 2000, akril, vászon / acril on canvas, $480 \times 80 \mathrm{~cm}$ 
Hogyan határozhatjuk meg a matematikát? Néhányan úgy gondolják, hogy egyfajta emberi alkotás, az a mód, ahogy gondolkodásunk a külső világ realitásának tartalmát vagy saját elménk alkotásait beágyazza, önmagában semleges és végső soron természetes dolog.

Mások, egyre többen, úgy látják a matematikát, mint egy valódi dolgot, mint önmagában létező birodalmat, mely ötvözi a formát a tartalommal, melyet maga a matematika formál, talán a forma által. Ilyen értelemben a matematika a 19. század óta egy határtalan óceánná vált, melyen saját magunk veszélyeztetésével navigálunk. Valódi kockázatok vannak itt az emberi elme számára és néha halálos veszélyek is. Ezt bizonyítja Georg Cantor, a kiváló matematikai gondolkodó élete. Pályafutása során időről időre pengeéles elméjét a végtelenség tárgyához rendelte, vagy ahogy ő nevezte, az „alefhez”. Az ár, amit nyughatatlan vizsgálataiért fizetett, nagyon magas volt. Kutatása szörnyü mentális összeomlásokat és elhúzódó pszichés szenvedést okozott, nagyon lassú felépüléssel. Az alef, a végtelen, olyan volt számára, mint Ulyssesnek a szirének, mindig visszatért hozzá szenvedései árán is.

A matematikus-filozófus Steven Galt Crowell (2001) egy másfajta megközelítést alkalmazott. Számára a matematika pusztán a jelentésről és a tartalomról szól. A minőség és a mennyiség ugyanaz, de különböző aggregációs állapotban, az egyik folyamatosan áramlik a másikba. Ezt hangsúlyozzák írásai Edmund Husserl és Martin Heidegger munkáiról is. Különösen Heideggert közvetíti hozzánk és az ő merengéseit a „Ráhagyatkozásról” (Gelassenheit), a létezés üzenetére való várakozásról, és az esszéit, mint például az Építeni, lakozni, elgondolkodni (Bauen, Wohnen, Denken), melyek számos szempontot ötvöznek, melyek szintén megtalálhatók a müalkotások születéséről szóló értekezéseiben. És szintén megjelennek Zalavári talapzatról felemelkedő müveiben is. Amikor a falon lógnak, néha látványosan négy pontra bomlanak, mint Heidegger „Négyessége" (Geviert), és ami a finom papírmunkáit illeti, művei csendben elmozdítják a harmóniát.

Más írók egy pillér puszta felemelkedéséről vagy egy Zalavári-munkáról mint egyfajta elsődleges emberi alkotásról beszéltek. Másrészről, jobban lenyügöz minket a számszerüség azon aspektusa, amely hirtelen megjelenik, és az egész környezetet a pályához vonzza, mint egy világ alapítása. Ez természetesen valami, ami az emberi teremtés tulajdonát képezi, legyen az egy őskori menhir felállítása a mai Franciaország területén, egy görög templom pillére, egy egyiptomi obeliszk elhelyezése, egy hatalmas istent ábrázoló szobor vagy akár Giacometti hosszú, karcsú szobrai, amelyek visszahozzák az istenit és az örökkévalót az embernek, annak végességével, hiányosságaival és 21. századi hibáival. Barabás Lajos mindkét szempontot látja, amikor az oszlopról beszél mint az univerzum tartójáról, az ég pilléréről, és úgy említi az oszlopállítást mint a világ teremtésének szertartását. 


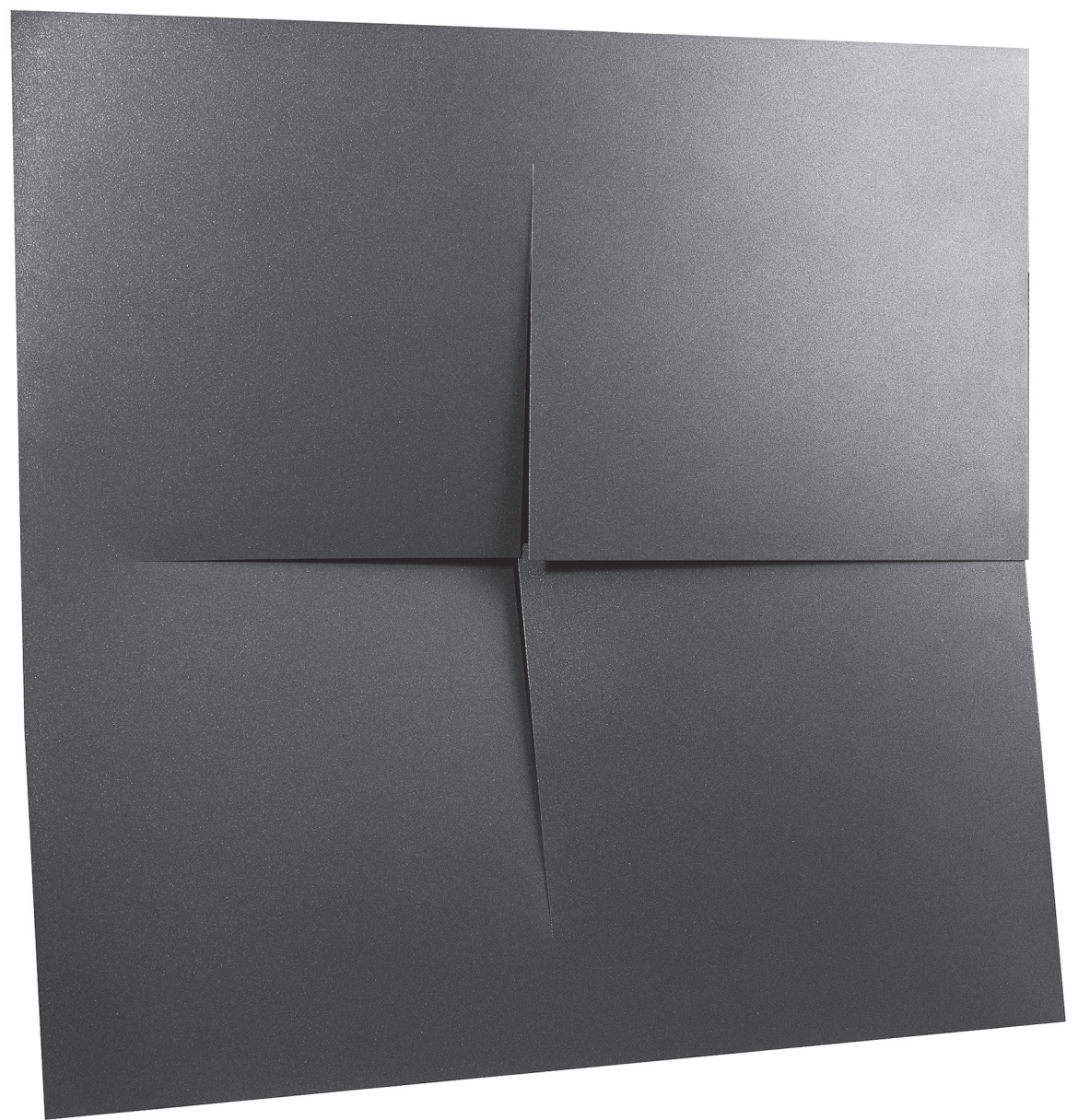

3. ábra. Elképzelt tér / Imagined space, 2017, aluminium, szinterezés

A modern müvészet, benne a konstruktivista müvészet alkotói közül sokan használták fel müveikben az oszlop motívumot, gondoljunk csak Max Billre vagy Gottfried Honeggerre. A kortárs magyar alkotók közül meg kell említeni Fajó Jánost, aki különböző anyagokból, fából, rézből, alumíniumból, rozsdamentes acélból alkotja oszlopszobrait több mint negyven éve.

Miért ez a nagy érdeklődés? A művészi buzgalom? Az oszlop egyetemes emberi szimbólum, az ősidőktől kezdve szinte mindegyik kultúrában előfordul.

A Helikon Kiadó Jelképtár címü kötetében Szemadám György jegyzi az „Oszlop" címszó leírását.

Az oszlop ,a világmindenség megtartója, az Ég támasza, az égi és a földi világ közti kapcsolat szimbóluma. Mint ilyen, az életfa-világfa egyszerüsített formája, 
s ezért a Nagy Istenanyával és a Világtengellyel is azonos. Az oszlopállítás már önmagában a világteremtési aktust jelképező rítus. Az oszlopok előbb töltöttek be kultikus szerepet, s később váltak építészeti támasztóelemmé."

Keresztény jelképként Szüz Máriát is szimbolizálhatja, a népi vallásosságban pedig „Magyarország több vidékén a ház középső, mennyezettartó oszlopát [...] boldogasszonynak vagy boldoganyának nevezik".

Edith Balas Brâncuşi és a román népmüvészet címü írásában írta: „... legjobb talán az 1937-38-ban készült Targu Jiu háborús emlékmúvel kezdeni. Három monumentális szobor képez csoportot: a Csend asztala, a Csók kapuja és a Végtelen oszlop..." (Barabás, 2018).

És akkor még mindig ott van az átmenet a korlátok nélküli végtelen és a végességgel együtt álló végtelen között a gondolkodásban és Zalavári müvészetében. Mindez az első pillanatban megjelenik, ahogy ránézünk, mert Zalavári mủvészete az „első pillanatról” szól, mely különböző művészeti formákban körbejárja a témát, vagy talán inkább spirálisan, hiszen egyetlen munkáját sem lehet a földhöz való visszatérésként jellemezni, amire Kozák Csaba mutat rá.

„A tárlat anyagát alfabetikus sorrendben Zalavári József művei zárják. Végtelen aszimmetria címü munkája egy lézervágott hajlított, rozsdamentes acélból készült oszlop. A fényes, vékony kolumna büszkén kanyarog az ég felé. Csavart teste spirált ír le, ami az élet körforgására, az örök megújulására, a kezdet és vég egybefonódására utal. A spirál a végtelen jele. Olyan, mint a geometria művészete: végtelen." (Kozák, 2018)

Az első pillanat a középszerüségben és a határtalanságban megjelenő különbség, a látszólag puszta „véletlenszerüség”, ahogy Zalavári néhány müvének elnevezése is mutatja. Úgy véljük, hogy Zalavári munkái az alkotás és gondolkodás első pillanatáról szólnak, kezdetben talán csak egy halvány tudatosság a létezésről és a „ott létről”, majd egy kibontakozás, és később egy virágzás a jelentés teljességében, ami a személyes öntudat. Meggyőződésünk, hogy utóbbi az, amiről az emberi lényünk kezdetben és végső soron is szól.

Ránézünk Zalavári fémmunkájára, és egy vagy két hosszú, egymást érintő fémszalagot látunk, egy vonal része, amely a semmiből jött, és sehová sem tart, szükségszerüen két pontnál elvágva, mint bármely más mủalkotás, szintén véges, de kezdetben hangsúlyozza és megtestesíti a töretlen folytonosságot. Aztán Zalavári megragadja a fémet, kissé megcsavarja, meghajlítja, és így megtöri a folytonosságot, a tökéletességet a fém különböző pontjain. A szemünk követi a vonalat felfelé vagy lefelé, aztán megállítják, vagy talán saját maga áll meg, és meghatároz egy pozíciót a fényes felületen. A fénypontok különböző irányokban táncolnak és kavarognak a szobron, megállnak, majd újra elindulnak, és később megszűnnek, hogy egyszer csak váratlanul a ragyogás pontjaiként újra feltűnjenek a kezdetben egyenes és makulátlan, de mostanra deformált és tökéletlen anyagon. 


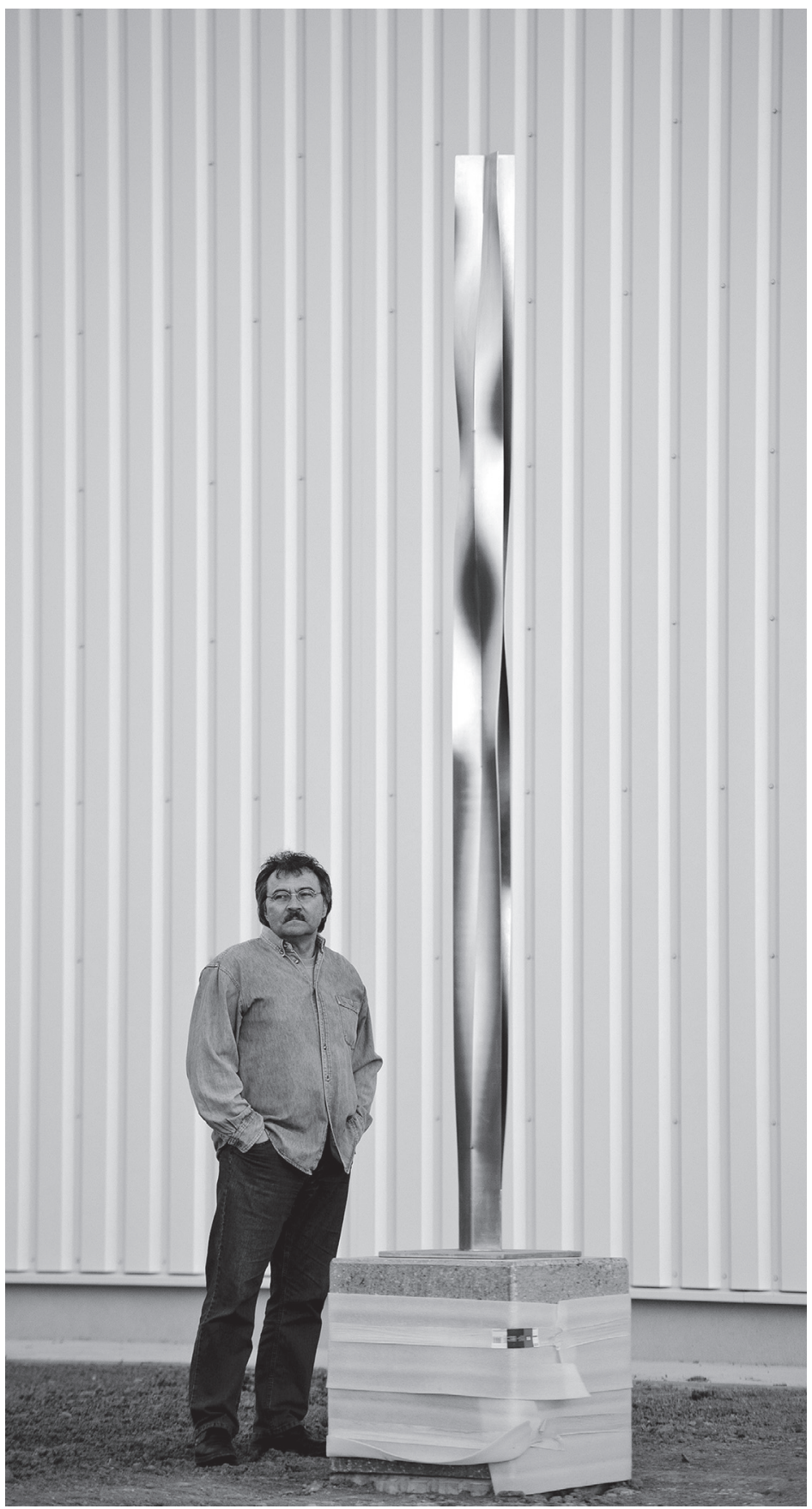

4. ábra. Végtelen aszimmetria / Endless asymmetry, 2014, rozsdamentes acél, $300 \times 16 \times 12 \mathrm{~cm}$, Hyundai-Kia Logisztikai Központ, Érd 
Ez az, amiről a végesség szól, mely a végtelen korlátozásával mutatja meg arcát, megszakítva a monoton, lineáris időt, amely mindig mozdulatlannak tünik. A filozófus Hegel ezt a vonalat „rossz végtelenségnek” minősíti, mivel nincs igazi előrelépés, csak az első pillanat örök ismétlődése. Nem spirál, hanem zárt kör. Pontosabban a természet ismeri az ismétlődést, de az időt egyáltalán nem. A 19. században néhány filozófus azt gondolta, hogy nincs igazi teremtés, és minden emberi erőfeszítés az első végtelen tökéletességhez való visszatérésből állhat, az első platóni ideához, többé-kevésbé helyreállítva azt, amelyet a végesség kibillentett az első pillanatban. Amikor ezt megpróbáljuk elképzelni és kinyitjuk a szemünket, visszatérünk az ókori Görögországba, abba a világba, melyet Nietzsche szerint „Ugyanannak örök visszatérése” felétételez. Az emberek iparkodtak visszatérni a tökéletességhez, mely egykoron volt... de nem teljesen, mert egy bizonyos pontnál tudatosan kellett csinálniuk valamit, hogy ezt elérjék. Habár a görög szobrok az embert mindig általában testesítik meg, még az istenek is tökéletes emberek, mindig ott volt az első csillogása valami többnek is.

Időzzünk el egy kicsit hosszabban az előbb említett „első pillanaton”, az örökkévalóság első megsértése a végesség tökéletlensége által, pontosabban, ez a tökéletesítö örökkévalóság, együtt a tökéletlenséggel most először helyettesíti az örök, „mozgás nélküli mobilitást” a valódi emberi idővel. Itt és most megmutatja a valódi teremtés idejét, mert csak valami „új” keletkezhet, amikor a jellegtelen végtelenség szakadt, törött, tépett, megváltozott, formázott, hajlított, csavart és sérült, hogy végül meggyógyuljon a teremtés örök sebhelyeit hagyva magán. Ezek mindegyike a valódi emberi idő és Zalavári munkáinak születésének előfeltételei, mind folyamatosan visszatér ehhez a bizonyos kiindulóponthoz, az idő és a teremtés első emberi pillanatához. Müvészetet teremt, mely müvészetteremtéssel mint idővel foglalkozik, és még sok minden mással. Úgy véljük, hogy e kettő nem létezhet egymás nélkül; idő és mủvészet.

Zalavári három kis papírdarabot mutat nekünk, melyek közül az egyik, ha a négyzet tökéletességét nézzük, kissé eltér a vonaltól, egy betörés, „körkörösségnek" nevezett müvet teremt, amely azonban a körnek egyetlen negyedét mutatja, nem többet. Most az idő valóban elkezdődött valahol, most az idő valóban áramlik, de soha nem tér vissza, lefekteti az alapjait annak, ami aztán az emberi szellemi fejlődés későbbi szakaszaiban a történeti tudatosság mélységeiben fog kivirágozni, a csúcspont, melyről úgy gondoljuk, minden emberi lehetőség csúcspontja.

„Zalavári József legújabb munkái négyzet alakú papírból készített reliefek. A lapokat bemetszett vagy rajzolt, párhuzamos, merőleges, diagonális, olykor köríves vonalak mentén osztja fel. Ezt követően a kompozíció szerint indokolt egyik vágásnál egymásra csúsztatja a síkokat, így térbeli formát nyer, miközben minden mozdul, hogy elnyerje végleges helyét. Az így létrejövő kompozícióban a vágott és rajzolt vonalak interaktivitása nem kérdéses. Az elöbbiek a fényárnyék hatásoknak köszönhetik létüket, így megjelenésükben szerepet játszik a 
látványillúzió, aminek aktuális minőségét a fényviszonyok határozzák meg. Az utóbbi - mint a valóság eszköze - a rajzolás müvészete elötti tisztelgés, ugyanakkor minimalista eszközzel megfogalmazott kompozíciós elem vagy eseményábrázolás. Az összkép szándékoltan csalóka: a vonalakkal vizuális és mentális készségeinket tréfálja, miközben a realitás és illúzió relációját is vizsgálja. A vonalak esetenkénti és váratlan eltünése vagy megtörése, szakadása, a folyamatosság és folytonosság hasonló elvű kérdését tárja fel: van, esetleg nincs? Mindezzel azonos időben a geometria létezése fölött meditál az alaptézisből kiindulva, miszerint: a geometria nem a természetben és az embertől függetlenül létező valóság. A papírreliefek keretbe helyezése e kérdésfeltevés termékeit emeli a müvészet szférájába, profánabb értelemben egyrészt védelmet ad a sérülésektől, másrészt kiemeli azt a néző közegéből.” (Szentandrási-Sós, 2018)

Néhányak számára ezek talán dicsekvő, nagy szavaknak tủnhetnek és tétlen spekulációnak egy vákuumban. Mások talán sértve érzik magukat, mert úgy tartják, hogy kizárólag Istennek van hatalma és privilégiuma a teremtéshez, és az emberi müvészek is tőle kapták képességüket mint ajándékot, munkáik létrehozására. Elnézést kérünk azért, ami talán sértőnek vagy udvariatlannak tünik, de gondoljunk Martin Heideggerre, aki azt mondja, hogy ,a kérdezés a gondolkodás hitelessége" (Das Fragen ist die Frömmigkeit des Denkens) (Heidegger, 1978, 44.).

Ismét Istenről beszélünk, a mủvészteremtőről, aki önmagában jelenti, hogy az egyénnek köze van az alkotóhoz, és ahogy mi gondoljuk, az alkotóerőhöz a szökkenő idő folyamán. Az egyén lényege, hogy tökéletlen, nem időben van, hanem ő maga az idő. Egy művész, mint Zalavári, a tárgyak alkotásával fejezi ki a saját maga és a mi jelen időnket azzal, hogy fizikaivá és láthatóvá teszi azt mások számára.

Zalavári munkáinak görbéit és a néha már zavaró megszakításait követő szemünk elmélyed az időben, mivel követnie kell a görbéket, és megállni a fém törésénél, továbbhaladni, átélni a kiegyensúlyozatlanság irritáló és bántó érzését a nagy, szürke, négy részre hajtott fémfelületen, melynek egy része szakadt, miért is ez a tüzvörös munka? Miért ez a csavar a már-már Möbius-szalagot idézö fémszalagban? Ha nézzük őket, az idő eredetét követjük a saját személyes időnkben. Barabás Lajos pontosan rámutat erre:

„Meglehetősen hosszúak, hogy egyszerre nézzük őket, de késztetik a szemünket, hogy a hullámok mentén kövessék.” Szintén megjegyzi, hogy „az oszlop a ritmus tartója" (Barabás, 2018).

Rendben, de ehhez szeretnénk hozzátenni; nemcsak a ritmus, hanem a szigorúan személyes dallam, néha még a szöveg is összefonódik vele, ami egyedivé és megismételhetetlenné tesz; nem kör, hanem spirál.

Zalavári József nem látványos installációkat alkot, hanem a müveiben lévő áramlás, a „flow”, a felületek kis fényei, melyek tekintetünkkel együtt önma- 
gukban mozognak, finoman ötvözik az erős és azonnali fizikai benyomást, melyet minden müalkotás kelt testünkön, szükségszerüen, az elménk megnyitásával. A lényegre összpontosít, díszítés vagy hivalkodás nélkül. Méltóságukban, a müvei kissé hasonlítanak a kiváló magyar müvész, Haász István alkotásaihoz, de nem egészen. Egy dolog azonban összehozza őket: mindketten úgynevezett „absztrakt” müvészetet teremtenek, néhányan talán konstruktivistának tartanák őket, de mindkét megközelítésről kiderül, hogy rendkívül személyes és felismerhető kifejezései a mủvészet első élményének és teremtésének. Ennek oka abban a tényben rejlik, hogy a megsértés tökéletlensége mindig nagyon személyes, és szemben áll a végtelenséggel, ami önmagában mindig személytelen és általános. A sima felület károsodása, karcolása és hajlítása egy személyes, mindig nagyon személyes sértés. És aztán a zene talán nem absztrakt, és a reakciónk nem rendkívül személyes?

Mindezek után arra a következtetésre jutunk, hogy Zalavári munkái csak kezdődnek a „térrel”, de szinte azonnal megjelennek az időben. Zsikla Mónikának igaza van: Zalavári „komponál”. A zene nemcsak absztrakt, hanem érzelmi és fizikai, testi dolog is? A zenének nincs köze az időhöz? Szintén egyetértünk abban, hogy Zalavári munkái, az első pillantás látványa ellenére, rokonságban állnak a barokkal.

„A Zalavári munkásságát méltató teoretikusok és müvészek szinte mind utalnak arra a minimalista hagyományra, amelyhez Zalavári szobrai és képi felületei kapcsolódnak. Mindig szó esik a geometrikus alapelemekről, a látványalkalmak színvilágának redukált, monokromasztikus letisztultságáról, a szobrokhoz felhasznált alapanyagok feszességéről és acélos sterilitásáról, a pengeélre állított egyensúlyról, és a kemény matériák légiessé tételéről. De a munkásságot méltatók egyike sem foglalkozott a mester minimalizmusában - szándékoltan vagy tudattalanul - elbújtatott barokk és manierista tobzódásokkal! Igen, igen, nem tévedés, valóban a barokkot emlegetem...

Első pillanatra talán merésznek és megdöbbentőnek tünik ez a párosítás, de a felületekhez közelebb lépve már nem tamáskodunk. A megvágott, ellenpontozott, csillogó és tükröződő acél- és szinterezett alumíniumszobrok önmagukban, szüzsé és fabula nélkül, a forma eleganciáját, az anyag tisztaságát és tiszteletét hirdetik, de a felületekhez kapcsolt »beszélő címek« olyan matematikai és geometriai konnotációkkal, antropomorf történetekkel és barokkos fordulatokkal ruházzák fel őket, amelyek a fegyelmezett és tudatos irányultság ellenére eltávolítják e szobrokat a minimalizmus szikár pragmatizmusától. A müvész által verbálisan megkeresztelt felületeket pedig többé már nem is vagyunk képesek másnak látni, mint amit a címük sugall: pároknak, szárnyaknak, érintőknek, kitérőknek, követőknek, madárnak, nyitott és végtelen aszimmetriának vagy épp szimmetriának. ...A látszólagos szúkszavúság, a redukált formák köntösébe bújtatott, vagy a róluk visszaverődő beszédes, fényes és mozgalmas barokkosság teremti meg Za- 
lavári felületeinek feszültségét. Azt a sohasem szünő feszültséget, amelynek hatókörében a formák és a fabulák, az anyag és az anyagtalan, a légies és a szilárd, a sötét és a fényes határmezsgyéjén szemlélődhetünk..." (Zsikla, 2016)

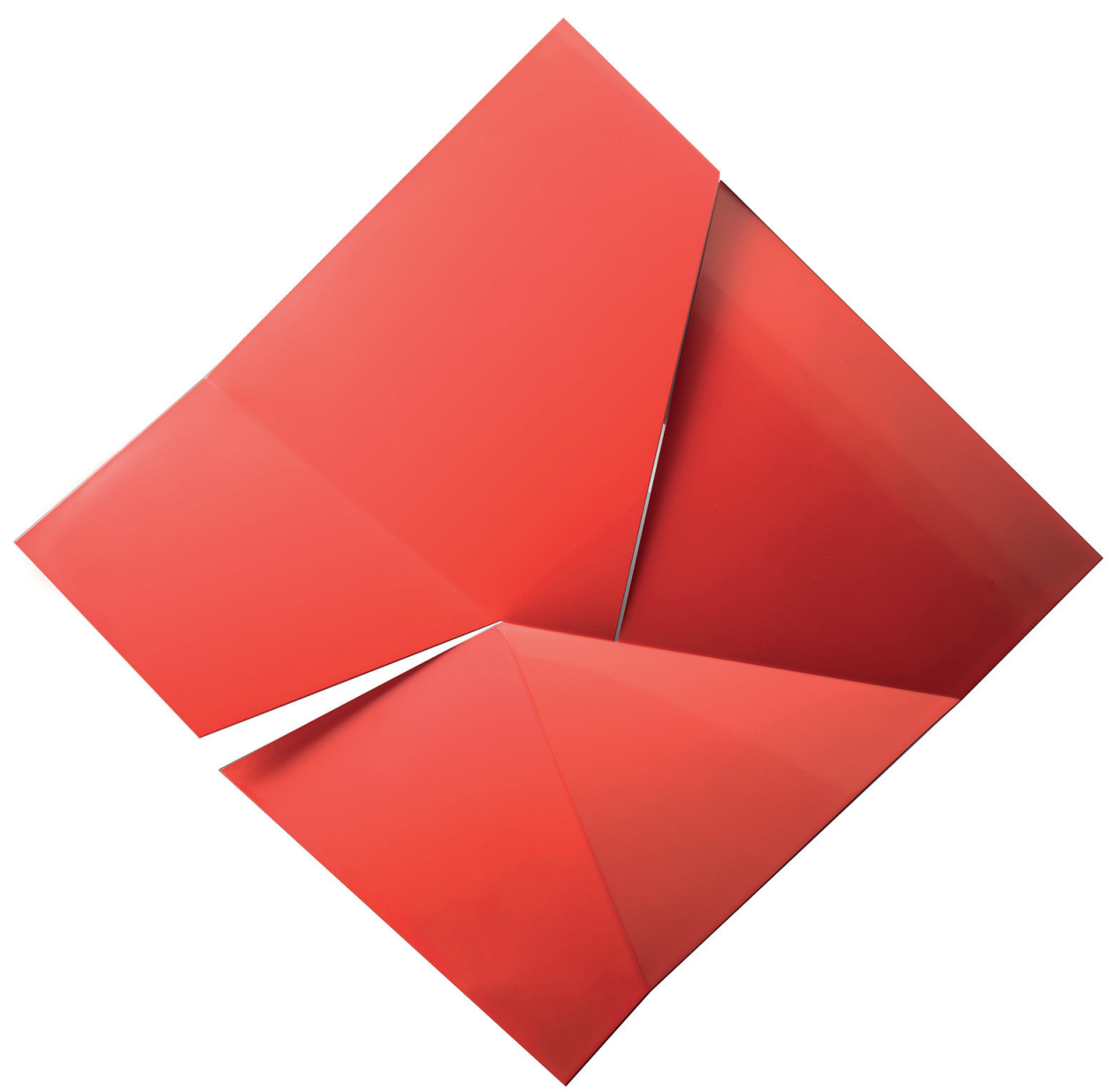

5. kép. Piros hold / Red Moon, 2018, aluminium, szinterezés, $85 \times 85 \mathrm{~cm}$

Még egy lépéssel tovább is mennénk, és összekötnénk öket a rokokóval, mivel a barokk és a rokokó örvénylő vonalait a nyughatatlan mozgásba és a végtelenségbe való belefeledkezés jellemzi. Zsikla Mónika azt mondja: „mindig változó és tükröződő", igen, a tükröződés kettős értelemben, az elme tükröződése, önreflexió, röviden: gondolkodás. Nos, mi lehet személyesebb és ugyanakkor személytelenebb, mint a gondolkodás? És úgy kell lennie, ahogy Arisztotelész már megjegyezte, hogy nem ismerjük a kizárólagosan jellemzőt. Igaz, hogy szükségünk van 
az általánosra a jellegzetessel együtt a fogalom kialakításához és az önismerethez való elérkezéshez.

Az öntudatosság ,belső” magunkkal kapcsolatos, de mindig, minden más emberrel is. Hegel szerint „Az én egy mi, a mi egy én” (Hegel, 1988, 120.). Zalavári szobraiban még ez is láthatóvá válik. Barabás Lajos utalt az „anyagba való betekintésre” és a „belső ragasztott felületek tükrözéséből eredő vonalak játékára” (Barabás, 2018). P. Szabó Ernő „izgalmas belső tereket” és „tükröző belső felületeket" említ.

„Elemi erők találkozásának lehetünk tanúi: a lemezt a szobrász néhány helyen bemetszi-befürészeli, majd egy speciális gépi technológiát alkalmazva néhány ponton nyomást gyakorol a lemezre. Ennek a nyomásnak s az anyag ellenállásának a kölcsönhatásaként formálódik át a rozsdamentes acéllap, lép ki a két dimenzióból a háromba, így születik meg az a szinuszgörbe, mely mindig csak az adott müre jellemző, így válik a statikus alkotásból sajátos kinetikus mü, amely a fénynek, a környezetet viszatükröző hatásának köszönhetően egyféle interaktív munkának is nevezhetö.

A folyamat egyik elágazási lehetőségét jelenti a fémlemez megkettőzése, aminek következtében izgalmas belső terek jönnek létre, illetve a belső tükröző felületek igen gazdag formajátékokat, ismétlődéseket, ellenpontokat hoznak létre.

A másik lehetőség, amikor a lemez helyét térbeli forma veszi át, amely alul és felül is háromszög alakú henger, a két végpont között azonban folyamatos formaalakulást figyelhetünk meg: egyrészt négy-hatszöggé alakul a test átmérője, másrészt pedig úgy törik meg a szobor többször is, úgy tünik, hogy a függőlegestől eltérő irányba fejlődik - miközben a müvek eme csoportjánál is megmarad a vertikális erővonal. Mi a valódi és mi a virtuális? Ezt kérdezhetjük a kiállítás legújabb alkotása, a második terem közepén látható mü, a Cseppek nézése közben. Hol a mü középpontja, hol kezdődik és hol ér véget a szobor tömege, kérdezi a szobrász, aki tömör rozsdamentes acélból készítette ezt az alkotást, amely azonban szinte súlytalanul lebegne néhány ezredmilliméterrel a talapzat felett. Elkészítése a jelen technológiája határait feszegeti. Létezése, jut az eszünkbe a szobor szemlélése közben, éppen olyan magától értetődő, mint annak a vízcseppnek a halála és folyamatos újjászületése, amelyre emlékeztet." (P. Szabó, 2018)

Valóban, néha Zalavári két fémszalagot rögzít egymásnak háttal, így teremtve sötétséget közöttük. Sötétség nélkül azonban Zalavári müvein nem lehet fény, nincs belső, nincs külső, nincs fényes „,visszaverődés”, egyáltalán nincs tükröződés, és ami a legfontosabb: nincs teremtés.

Itt ismét visszatérünk az első pillanatra és minden eredet eredetére, mely Zalavári József minden sikeres munkáját körülveszi. Emlékeznünk kell annak a könyvnek az első soraira, amely a nyugati civilizációnkat és sok mást is formált. „Kezdetben teremtette Isten a mennyet és a földet. A föld még kietlen és puszta 
volt, a mélység fölött sötétség volt, de Isten Lelke lebegett a vizek fölött. Akkor ezt mondta Isten: Legyen világosság! És lett világosság."1

\section{IRODALOM}

Barabás L. (2018): Zalavári. In: Zalavári „Imagine”. Katalógus. Budapest: Hotel Mercure Museum Gallery, 2014. szeptember 1.

Budapest Müvészeti Galéria (2014): Zalavári. In: Zalavári „Imagine”. Katalógus. Budapest: Hotel Mercure Museum Gallery, 2014. szeptember 1.

Crowell, S. G. (2001): Husserl, Heidegger and the Space of Meaning. Evanston, IL: North Western University Press

Hegel, G. (1988): Phänomenologie des Geistes. Hamburg: Felix Meiner Verlag

Heidegger, M. (1978): Vorträge és Aufsätze, 4. Pfullingen

Hoppál M. - Jankovics M. - Nagy A. -Szemadám Gy. (2004): Jelképtár. Budapest: Helikon Kiadó

Kozák Cs. (2018): SZÍN-FORMA-TÉR. Geometriai tendenciák a kortárs magyar művészetben. In: Zalavári „Imagine”. Katalógus. Budapest: Hotel Mercure Museum Gallery, 2014. szeptember 1.

P. Szabó E. (2018): Lát-hatás. Zalavári szobrok az Érdi Galériában. Magyar Nemzet, 2013. szeptember 4. In: Zalavári „Imagine”. Katalógus. Budapest: Hotel Mercure Museum Gallery, 2014. szeptember 1 .

Szentandrási-Sós Zs. (2018): Papírreliefek. In: Zalavári „Imagine”. Katalógus. Budapest: Hotel Mercure Museum Gallery, 2014. szeptember 1.

Szöllősi-Nagy A. (2005): Kis elmozdulások: Szubjektív előszó és kulcsszavak Zalavári morfémáihoz. In: Zalavári katalógus. Morphemes. Párizs, 2005. október

Zsikla M. (2016): Zalavári József: Sötét és világos. 2016. március 29. byArt galéria

${ }^{1}$ A Magyar Bibliatársulat újfordítású Bibliája (1990) 